\title{
Application of Scientific Method in Evaluating the Subject Matter of Spellers*
}

\section{Clifford Woody}

To cite this article: Clifford Woody (1920) Application of Scientific Method in Evaluating the Subject Matter of Spellers*, The Journal of Educational Research, 1:1-2, 119-128, DOI: 10.1080/00220671.1920.10879031

To link to this article: http://dx.doi.org/10.1080/00220671.1920.10879031

册Published online: 12 Jan 2015.

Submit your article to this journal $₫$

Џll Article views: 1 


\title{
APPLICATION OF SCIENTIFIC METHOD IN EVALUATING THE SUBJECT MATTER OF SPELLERS*
}

\author{
Clifford Woody \\ University of Washington
}

Within the last decade the dominant note in educational theory has been the social point of view - that the needs of society should furnish the end points of education and should serve as a basis for the selection of subject matter. This philosophy has been urged as applicable to all phases of educational activity and the insistence on its application has resulted in many recent investigations to determine scientifically the needs of society and the consequent subject matter. In no field have these investigations been more fruitful than in spelling and the educational theorist can look with great satisfaction upon the scientifically determined lists of most commonly used words representing the social need for spelling. But the realization of his hope has merely begun, for these scientifically determined lists of most commonly used words will have little influence until they have been incorporated in to the spellers which are used throughout the length and breadth of this country, since the textbook has become such a dominant force in the life of the American teacher that it tends to determine the aims, the subject matter, and the method of instruction. The use of the properly constructed textbook then is the real answer to the theorist's demand for emphasis on the social point of view.

The present study was undertaken to show the possibility of evaluating the subject matter of spellers and of scientifically selecting a book having its vocabulary made up of the most commonly used words. It represents a comparison of the Anderson list of most commonly used words-a list containing 3,105 words used 5 or more times selected from the 361,184 running words which composed the contents of 3,723 business and social letters written by adults - and the vocabularies of five widely used

*The statistical tabulations utilized in this article were made by Frank $\mathbf{S}$. Salisbury and the author is indebted to him for the privilege of using them in this article. 
spellers: 1) Champion Spelling Book, ${ }^{1}$ 2) Peirce Spellers, ${ }^{2}$ 3) Merrill Speller, ${ }^{3}$ 4) Aldine Spellers, ${ }^{4}$ 5) The Child's Own Spelling Book. ${ }^{5}$ The Anderson list ${ }^{6}$ was selected because it represents the latest and most comprehensive of all the attempts to select the most commonly used words and includes a very large percent of the Ayres and Pryor lists. The first three spellers mentioned were selected because they are widely used in the state of Washington; the fourth one, because the preface indicates that the vocabulary researches have been utilized to a considerable extent in the word content of the book; the fifth one, because its subject matter - stands as the direct product of a study of children's writing vocabularies. In making these comparisons, the subject matter of the different spellers was the only factor taken into consideration-no attention being given to physical features of the books, provisions for review, suggestions for teachers, suggested methods, gradation of words, or price. It is true that a complete survey of the books demands that all these factors be given due consideration but in the selection of a speller it is assumed that the spelling vocabulary is of primary importance.

In making the tabulations the words of the Anderson list were transcribed onto three by five inch cards-one word being placed on a card - and the cards were arranged alphabetically, indexed, and filed. Word by word, the vocabulary of each speller was checked with the words of the Anderson list. Records were made of the words common to a particular speller and to the list, of the words that were in the list but not in the particular speller, and of those words that were in the particular speller but not in the list. Hereafter reference will be made to these groups of

${ }^{1}$ Hicks, W. E. Champion spelling book for public and private schools. New York: American Book Co., 1909.2 pts.

${ }^{2}$ Peirce, W. N. Peirce spellers. New York: Ginn \& Co., 1912-13. 2 bks.

${ }^{3}$ Wilson, J. O. Merrill speller. New York. Charles E. Merrill, 1912. 2 bks.

${ }^{4}$ Bryce, C. T. and Sherman, F. J. Aldine spellers. New York: Newson \& Co., 1916. 4 bks.

${ }^{5}$ Jones, W. F. Child's own spelling book. Pierre, S. D.: Capital Supply Co., 1915. 2 bks.

${ }^{6}$ Anderson, W. N. The determination of a spelling vocabulary based upon written correspondence. Master's dissertation, University of Iowa, 1917. This list is substantially reproduced in E. J. Ashbaugh's Iowa spelling scale for grades II to VIII (University of Iowa Extension Bulletin, no. 34-36, September 1-October 1, 1919). 
words as "overlap" words, "list only" words, and "speller only" words.

Wherever a word in the list occurred more than once in a particular book the fact was noted and in estimating the amount of overlapping such a word was given but a single count. It was originally intended to record the repetitions for the "speller only" words, but since the primary interest of the study lay in the overlapping of the spellers with the Anderson list and since the repetition of the "speller only" words would have no bearing on the problem save on total number of words in the different books, the amount of repetition was estimated as existing in the same ratio as the repetition in "overlap" of the list and a particular

TABLE I. GROSS COMPARISONS OF THE FIVE SPELLERS WITH THE ANDERSON LIST

\begin{tabular}{c|c|c|c|c|c|c|c}
\hline \hline Spellers & Grades & $\begin{array}{c}\text { Total } \\
\text { Words } \\
\text { in Book }\end{array}$ & $\begin{array}{c}\text { "Speller } \\
\text { Only" } \\
\text { Words }\end{array}$ & $\begin{array}{c}\text { "Over- } \\
\text { lap" } \\
\text { Words }\end{array}$ & $\begin{array}{c}\text { "List } \\
\text { Only" } \\
\text { Words }\end{array}$ & $\begin{array}{c}\text { Percent } \\
\text { of Book } \\
\text { Repre- } \\
\text { sented } \\
\text { by } \\
\text { "Overlap" }\end{array}$ & $\begin{array}{c}\text { Percent of } \\
\text { Anderson } \\
\text { List } \\
\text { Included }\end{array}$ \\
\hline I & 2 & 3 & 4 & 5 & 6 & 7 & 8 \\
\hline Champion & $3-8$ & $\begin{array}{c}6,270 \\
(5,872)\end{array}$ & $\begin{array}{c}4,846 \\
(4,430)\end{array}$ & 1,424 & 1,681 & $\begin{array}{c}22.7 \\
(24.2)\end{array}$ & 45.9 \\
\hline Peirce.... & $3-8$ & $\begin{array}{c}2,991 \\
(2,862)\end{array}$ & $\begin{array}{c}2,207 \\
(2,078)\end{array}$ & 784 & 2,321 & $\begin{array}{c}26.2 \\
(27.0)\end{array}$ & 25.2 \\
\hline Merrill... & $3-8$ & $\begin{array}{c}5,636 \\
(5,550)\end{array}$ & $\begin{array}{c}3,959 \\
(3,873)\end{array}$ & 1,677 & 1,428 & $\begin{array}{c}30.0 \\
(30.0)\end{array}$ & 54.0 \\
\hline Aldine... & $1-8$ & $\begin{array}{c}4,786 \\
(4,436)\end{array}$ & $\begin{array}{c}2,801 \\
(2,451)\end{array}$ & 1,985 & 1,120 & $\begin{array}{c}41.5 \\
(44.9)\end{array}$ & 63.9 \\
\hline Jones.... & $2-8$ & 4,532 & 2,637 & 1,895 & 1,210 & 41.8 & 61.3 \\
\hline
\end{tabular}

The figures without parentheses in columns 3,4 , and 7 are only approximately true, for as was noted previously only the gross number of "speller only" words was obtained, the amount of repetition therein being disregarded. Hence a slight source of error in the figures of these columns. The figures in parentheses in the columns represent the same results on the assumption that the repetition in the "speller only" words is the same as in the "overlap" words. 
speller. Record was also kept of the particular grade in which each word in each speller was taught.

The facts concerning the overlapping of the five spellers and the Anderson list are presented in Table I. The first column of this table gives the name of the speller; the second column, the grades in which it is supposed to be used; the third column, the total number of words in the book; the fourth column, the number of "speller only" words; the fifth column, the number of "overlap" words, i.e., words common to the speller and the list; the sixth column, the "list only" words, i.e., words in the Anderson list but not included in the book; the seventh column, the percent of the total number of words in the speller represented by the "overlap" words; the last column, the percent of the Anderson list incorporated in the speller.

Table I makes it evident that if the number of words included in the "overlap" (column 5), or if the percent of the Anderson list included in the "overlap" (column 8) is taken as a basis of comparison, the relative standing of the books is as follows: Aldine first, with 1,985 "overlap" words representing 63.9 percent of the Anderson list; Jones second, with 1,895 "overlap" words representing 61.3 percent of the Anderson list; Merrill third, with 1,677 "overlap" words representing 54.0 percent of the Anderson list; Champion fourth, with 1,424 "overlap" words representing 45.9 percent of the Anderson list; Peirce fifth, with 784 "overlap" words representing but 25.2 percent of the Anderson list.

To the practical minded superintendent the above comparison is fair and just for since the speller determines to so great an extent what words will be taught it is logical to insist that the subject matter of that book is best which contains the greater number or percent of the commonly used words. However, the Champion, the Peirce, and the Merrill, as shown in column 2, are intended for grades III to vIII-inclusive; the Aldine, for grades I to VIII inclusive; and the Jones, for grades II to viII inclusive. Consequently one might expect differences in the total number of words in the spellers and more chances of overlapping in those books containing the most words. Column 3 shows that the books do vary greatly in the total number of words included-from 2,991 in the Peirce speller to 6,270 in the Cham- 
pion-but comparisons with other columns in the table show little relation between the number of words in the book and the amount of overlapping. Column 7 shows that in the Aldine and Jones spellers the "overlap" is a little over 40 percent of the total spelling vocabulary while in the other spellers it ranges from 22.7 to 30 percent. Such facts tend to show the superiority of these first mentioned spellers.

To eliminate the charge that it is unfair to compare books primarily intended for grades III to VIII inclusive with those intended for more than these grades, comparisons were made disregarding the word lists in the Aldine and the Jones spellers intended for grades below the third. From Table II representing such comparison it is seen that the Jones and Aldine spellers still rank very high in the number and percent of the Anderson lists included in the "overlap" but the Merrill speller ranks higher. When comparison is made of the percent of the book total repre-

TABLE II. COMPARISON OF THE FIVE SPELLERS WITH THE ANDERSON LIST ON THE BASIS OF THE WORD LIST FOR GRADES III TO VIII INCLUSIVE

\begin{tabular}{c|c|c|c|c|c|c|c}
\hline \hline Speller & Grades & $\begin{array}{c}\text { Total } \\
\text { Words } \\
\text { in Book }\end{array}$ & $\begin{array}{c}\text { "Speller } \\
\text { Only" } \\
\text { Words }\end{array}$ & $\begin{array}{c}\text { "Over- } \\
\text { lap" } \\
\text { Words }\end{array}$ & $\begin{array}{c}\text { "List } \\
\text { Only" } \\
\text { Words }\end{array}$ & $\begin{array}{c}\text { Percent } \\
\text { of Book } \\
\text { Repre- } \\
\text { sented } \\
\text { by “Over- } \\
\text { lap" }\end{array}$ & $\begin{array}{c}\text { Percent } \\
\text { of Ander- } \\
\text { son List } \\
\text { Included } \\
\text { in "Over- } \\
\text { lap" }\end{array}$ \\
\hline 1 & 2 & 3 & 4 & 5 & 6 & 7 & 8 \\
\hline Champion & $3-8$ & $\begin{array}{c}6,270 \\
(5,872)\end{array}$ & $\begin{array}{c}4,846 \\
(4,430)\end{array}$ & 1,424 & 1,681 & $\begin{array}{c}22.7 \\
(24.2)\end{array}$ & 45.9 \\
\hline Peirce... & $3-8$ & $\begin{array}{c}2,991 \\
(2,862)\end{array}$ & $\begin{array}{c}2,207 \\
(2,078)\end{array}$ & 784 & 2,321 & $\begin{array}{c}26.2 \\
(27.0)\end{array}$ & 25.2 \\
\hline Merrill... & $3-8$ & $\begin{array}{c}5,636 \\
(5,550)\end{array}$ & $\begin{array}{c}3,959 \\
(3,873)\end{array}$ & 1,677 & 1,428 & $\begin{array}{c}30.0 \\
(30.0)\end{array}$ & 54.0 \\
\hline Aldine... & $3-8$ & $\begin{array}{c}3,888 \\
(3,400)\end{array}$ & $\begin{array}{c}2,429 \\
(1,941)\end{array}$ & 1,459 & 1,646 & $\begin{array}{c}40.0 \\
(43.0)\end{array}$ & 47.0 \\
\hline Jones... & $3-8$ & 4,008 & 2,524 & 1,484 & 1,621 & 37.0 & 47.7 \\
\hline
\end{tabular}


sented by the "overlap" then it is clear that the Jones and the Aldine spellers contain a much smaller percent of words of "low probability of usefulness."

Thus far all comparisons have been made with the Anderson list as a whole; but, as was pointed out by Ayres in his attempt to identify the two thousand most commonly used words, the greater the number of words the more they vary according to the subject matter under consideration, and the less reliable the conclusion about their being most commonly used. Consequently the Anderson list was divided into six parts. Part I consists of the 79 words that make up the first five deciles of the Anderson list, i.e., those words which with all their repetitions account for five-tenths of the 361,184 running words that are contained in the Anderson source material. Part II consists of the 213 words in the sixth and seventh deciles. Part III consists of the 303 words of the eighth decile. Part IV consists of the 849 words of the ninth decile; Part $V$ consists of 1,661 words of the tenth decile which were used 5 or more times. Part VI consists of the remaining 6,118 words of the tenth decile-those words in the Anderson source material but not listed as most commonly used words.

The number of words in the different parts together with the variation of the number of times the different words were used are presented in tabular form below.

TABLE III. SHOWING NUMBER OF WORDS IN THE DIFFERENT

PARTS AND THE VARIATION IN THE NUMBER OF TIMES

THE VARIOUS WORDS USED

\begin{tabular}{c|c|c}
\hline \hline Number of Parts & Number of Words & $\begin{array}{c}\text { Range in Number } \\
\text { of Times Used }\end{array}$ \\
\hline & & \\
I & 79 & $677-11,893$ \\
II & 213 & $185-675$ \\
III & 303 & $79-185$ \\
IV & 849 & $24-79$ \\
V & 1,661 & $5-24$ \\
VI & 6,118 & $1-5$ \\
\hline
\end{tabular}

A glance at Table III shows that each part varies in two respects, the number of words and the number of times the words 
were used. It is furthermore noted that where there are few words in a part they are used many times and where there are many words they are used few times. "Few words and many times used" signifies most commonly used words, and "many words and few times used" signifies words of low probability of usefulness. Consequently that book which contains the highest number and percent in the first parts of the list will contain the most of the commonly used words.

Table IV, showing the number of words in the five spellers that are found in each of the six parts of the Anderson source material, reveals great variation among the different books in the number of words found in the respective parts. It is interesting to note that the Aldine and the Jones spellers usually contain more words in Parts I to V inclusive and fewer words in Part VI. These facts stand out more prominently in Table V, which presents the figures for Parts $\mathrm{I}$ to $\mathrm{V}$ inclusive reduced to percents.

TABLE IV. NUMBER OF WORDS IN THE FIVE SPELLERS THAT ARE FOUND IN EACH PART OF THE ANDERSON SOURCE MATERIAL

\begin{tabular}{|c|c|c|c|c|c|c|}
\hline $\begin{array}{c}\text { Spellers } \\
\text { with Book } \\
\text { Total }\end{array}$ & $\begin{array}{l}\text { Part I } \\
(79 \\
\text { words })\end{array}$ & $\begin{array}{l}\text { Part II } \\
(213 \\
\text { words) }\end{array}$ & $\begin{array}{l}\text { Part III } \\
(30.3 \\
\text { words })\end{array}$ & $\begin{array}{l}\text { Part IV } \\
(849 \\
\text { words })\end{array}$ & $\begin{array}{l}\text { Part V } \\
(1,661 \\
\text { words) }\end{array}$ & $\begin{array}{c}\text { Part VI } \\
(6,118 \\
\text { words })\end{array}$ \\
\hline $\begin{array}{l}\text { Champion } \\
5,872-6,270 \ldots \ldots\end{array}$ & 19 & 113 & 181 & 452 & 659 & $4,500-4,800$ \\
\hline $\begin{array}{l}\text { Peirce } \\
2,862-2,991 \ldots \ldots\end{array}$ & 8 & 52 & 88 & 255 & 381 & $2,000-2,200$ \\
\hline $\begin{array}{l}\text { Merrill } \\
5,550-5,636 \ldots \ldots\end{array}$ & 30 & 153 & 216 & 466 & 812 & $3,775-3,950$ \\
\hline $\begin{array}{l}\text { Aldine } \\
4,436-4,786 \ldots \ldots\end{array}$ & 79 & 118 & 206 & 618 & 946 & $2,500-2,800$ \\
\hline $\begin{array}{l}\text { Jones } \\
4,532 \ldots \ldots\end{array}$ & 76 & 200 & 255 & 569 & 795 & 2,636 \\
\hline
\end{tabular}

Table V should be read as follows: The Champion speller, which as a book included 45.9 percent of the 3,105 words of the Anderson list, contained 24 percent of Part I, 53 percent of 
TABLE V. PERCENT OF THE ANDERSON LIST AND OF THE FIRST FIVE PARTS CONTAINED IN EACH SPELLER

(Computed from Table IV)

\begin{tabular}{|c|c|c|c|c|c|}
\hline $\begin{array}{l}\text { Speller with } \\
\text { Percent of } \\
\text { Anderson } \\
\text { List Included }\end{array}$ & $\begin{array}{c}\text { Part I } \\
\text { (79 words) }\end{array}$ & $\begin{array}{c}\text { Part II } \\
\text { (213 words) }\end{array}$ & $\begin{array}{c}\text { Part III } \\
\text { (303 words) }\end{array}$ & $\begin{array}{l}\text { Part IV } \\
\text { (849 words) }\end{array}$ & $\begin{array}{c}\text { Part V } \\
(1,661 \text { words })\end{array}$ \\
\hline $\begin{array}{l}\text { Champion } \\
45.9 \ldots \ldots\end{array}$ & 24 & 53 & 60 & 53 & 40 \\
\hline $\begin{array}{l}\text { Peirce } \\
25.2 \ldots \ldots\end{array}$ & 10 & 24 & 29 & 30 & 23 \\
\hline $\begin{array}{l}\text { Merrill } \\
54.0 \ldots \ldots\end{array}$ & 38 & 73 & 71 & 55 & 49 \\
\hline $\begin{array}{l}\text { Aldine } \\
63.9 \ldots \ldots\end{array}$ & 100 & 55 & 68 & 73 & 58 \\
\hline $\begin{array}{l}\text { Jones } \\
61.3 \ldots \ldots \ldots\end{array}$ & 96 & 94 & 84 & 67 & 48 \\
\hline
\end{tabular}

TABLE VI. SCORES WHEN THE PERCENTS OF OVERLAPPING GIVEN IN TABLE V ARE WEIGHTED ACCORDING TO THE NUMBER OF DECILES IN EACH PART

\begin{tabular}{|c|c|c|c|c|c|c|}
\hline Speller & $\begin{array}{c}\text { Part I } \\
(500)\end{array}$ & $\begin{array}{c}\text { Part II } \\
(200)\end{array}$ & $\begin{array}{c}\text { Part III } \\
\quad(100)\end{array}$ & $\begin{array}{c}\text { Part IV } \\
(100)\end{array}$ & $\begin{array}{c}\text { Part V } \\
(50)\end{array}$ & $\begin{array}{l}\text { Total } \\
(950)\end{array}$ \\
\hline 1 & 2 & 3 & 4 & 5 & 6 & 7 \\
\hline Champion......... & 120 & 106 & 60 & 53 & 20 & 359 \\
\hline Peirce.............. & 50 & 48 & 29 & 30 & 12 & 169 \\
\hline Merrill............. & 160 & 146 & 71 & 55 & 25 & 457 \\
\hline Aldine....... & 500 & 110 & 68 & 73 & 29 & 780 \\
\hline Jones. . & 480 & 188 & 84 & 67 & 24 & 843 \\
\hline
\end{tabular}


Part II, 60 percent of Part III, 53 percent of Part IV and 40 percent of Part V, etc. This table merely serves to reemphasize the superiority of the Jones and Aldine spellers when checked against the Anderson list of commonly used words.

To give a more complete evaluation of the books on the basis of their selection of commonly used words, the parts were weighted according to the number of deciles or the part of a decile which the words therein comprise. Table VI showing the results of such weightings is derived from Table $\mathrm{V}$ by multiplying the percents for Part I by 5, i.e., the number of deciles in that part; the percents for Part II by 2 ; for Part III by 1 ; for Part IV by 1 ; for Part V by $1 / 2$. By this system of weighting the perfect scores for Parts I to V respectively are 500, 200,100,100, and 50; ard the perfect score for the five parts taken together 950 .

The total scores as given in column 7 show that the spellers should be ranked as follows: Jones, first; Aldine, second; Merrill, third; Champion, fourth; Peirce, fifth.

It should be pointed out that even though the Jones speller is given first rank according to the weighted scores, the Aldine speller has a higher score in three of the five parts. When the books were ranked according to the percent of the Anderson list included (Table I), the Aldine speller excelled the Jones by a narrow margin. When the books were ranked on the basis of the word lists for grades III to vIII inclusive (Table II) the Jones speller excelled by seven-tenths of one percent. All of these facts tend to show that little difference exists between these two spellers, and that superintendents and teachers would make little mistake in choosing either book, so far as spelling vocabulary is concerned.

On the whole, this study shows a great range in the size of the spelling vocabulary-from 2,991 words in the Peirce speller to 6,270 words in the Champion speller. It also shows the significant fact, so far as these books are concerned that little relation exists between mere size of vocabulary and the number of most commonly used words included. For example the Champion speller with 6,270 words contains but 45.9 percent of the Anderson list while the Jones speller with 4,532 words contains 61.3 percent of the list-which fact signifies that the selection of a spelling vocabulary is something more than merely collecting so many words. The study also shows that the ratio of the number of 
commonly used words to total number of words in the book varies from 41.8 percent in the Jones speller to 22.7 percent in the Champion speller. In cold facts these figures mean, if we may safely argue from the basis of the Anderson list, that from 58 to 77 percent of the time devoted to spelling within the public school is spent upon words not commonly used. Is not one cause of the charge sometimes heard today that children are not efficient in spelling due to the fact that we teach the children one list of words in the school room and the world expects them to spell another list when they leave the school room?

The study shows that the Jones and Aldine spellers rank high, no matter whether considering the number or percent of the Anderson list included, the ratio of the words of the Anderson list to the total number of words in the book, or the final scores determined through the adopted system of weighting the words according to their position in the Anderson list. When only the vocabularies intended for grades III to vIII inclusive are compared the Merrill speller includes a higher number and percent of the list, but this speller is surpassed by the previously mentioned books in all other phases considered.

One must conclude then that the Jones and Aldine spellers are superior to the other three spellers under consideration as far as choice of vocabulary is concerned. This does not mean that they are superior in other respects, nor does it mean that they are superior to other spellers on the market today, especially those which have just recently come from the press. The selection of a speller, to be wholly scientific, should take account of all spellers and all aspects of the different spellers; but this was impossible in the present investigation. Such investigations require time and energy; but it can safely be predicted that until they are made we shall continue to select books, which cause children to spend their time upon words which they will probably never use, and we shall continue to select books incorporating inferior methods. Proper utilization of scientific method in the selection of spellers or other textbooks will hasten the application of the best established psychological principles and will guarantee progress in the realization of the social point of view. 